\title{
8 Water and Decentring Urbanism in the Roman Period: Urban Materiality, Post-Humanism and Identity
}

\begin{abstract}
In this chapter, the relationship between water and urbanism in the Roman period is examined by looking at the ways in which water formed part of the urban fabric and the implications of this for understanding urban development, urban lives and identities, that decentres approaches to Roman urbanism. Water reminds us that the dualism of 'natural' and 'humanmade' components of settlements and landscapes needs to be studied and brought together through meaningful frameworks of analysis. 'Decentring' urbanism draws on different perspectives of urbanism and allows us to move away from the top-down Romanocentric approach to urban studies and look for additional perspectives and experiences. The example of water allows us to explore urbanism by looking at landscape, religion and ritual, and identity and experience. The paper focuses on the towns of Britain in the Roman era, with case studies of Colchester (Camulodunum), St Albans (Verulamium), London (Londinium), Lincoln (Lindum) and Winchester (Venta Belgarum), and reflects on the way in which provinces across the Empire differed in the nature of urban development and urban experience. There was no one Roman world, but many different worlds in the Roman era where there were different identities and experiences.
\end{abstract}

\section{Introduction}

This paper examines water as a component of towns in the Roman period and how we can look at the implications of water forming part of the urban materiality. Water can be used to develop decentred perspectives on these settlements and the experiences of inhabitants. This study draws on completed and ongoing work undertaken by the author on themes connected with urbanism in the Roman period, and the relationship between settlement and water in archaeology, as well as the interconnected themes of identity and experience. ${ }^{1}$ The work has included the documentation and analysis of the way in which the water formed part of townscapes and how towns developed and altered the waterscapes of the areas in which they were founded. This alteration and use of landscape included the construction of port and harbour facilities, whose impact went beyond economic function and also had social implications. ${ }^{2}$

The paper addresses the way in which water can be regarded as an integral component of the materiality of towns. In other words, the issue of how human-made and 'natural' elements of towns can be given equal prominence, breaking down dualisms in academic study and thinking about post-humanism, in the analysis of urban composition and what the implications of this is for understanding towns and the urban experience. Water formed part of the landscapes of many of the places where towns were constructed and developed in the Roman period and water continued to form part of the urban fabric. This also meant that the water formed part of the way in which the identity and experience of the town residents were created. Many of the waterscapes in which towns were founded, and formed a part were altered in the Roman period as towns developed, but there is also evidence that some at least of these watery places continued to have a significance that drew on earlier meanings associated with these places. Thinking about water in towns in this way has implications for 'decentring' urbanism, where 'decentring'

1 E. g. Rogers 2011; Rogers 2012a; Rogers 2012b; Rogers 2013; Rogers 2016.

2 E. g. Rogers 2011.

Ә Open Access. ๑ 2020 Adam Rogers, published by De Gruyter. (c) BY-NC-ND This work is licensed under the Creative Commons Attribution-NonCommercial-NoDerivatives 4.0 License.

https://doi.org/10.1515/9783110677065-008 
allows local processes and meanings to be prioritised over the top-down Romanocentric approach. This in turn allows us to address, from a critical perspective, the issue of Romanisation and identity in the Roman period.

\section{Water and city development in urban theory: Roman studies and beyond}

Decentring is a term taken from post-colonial theory and reflects the desire within colonial contexts to move away from the top-down hierarchical approach and instead to emphasise local circumstances and experiences. Decentring has geographical implications in placing the emphasis away from the colonial power and instead looking at the impact on regional areas and the unique issues that concern each area. It looks at the combination of local agency and colonial influences. Decentring, however, also allows us to ask different questions of the data. It deprioritises the themes that we tend to focus on, and the questions that we ask of the material, and instead allows us to interpret the data from different perspectives and intellectual frameworks.

Developments within post-colonial studies argue that non-Western forms of urban settlement should not be regarded as inferior to Western forms of urban development. There is also a questioning of the way in which urban settlements are placed in hierarchies of importance with many non-Western or early Western urban sites described as proto-urban rather than urban; Western cities are also seen as superior to non-Western settlements. Tim Edensor and Mark Jayne have argued that we need to decentralise the way in which we approach urban studies. ${ }^{3}$ This means that we need to move urban theory away from a preoccupation with Western urbanism. This is not only about treating non-Western settlements equally, but also thinking about how non-Western sites can be investigated from different, non-Western perspectives, and how these themes can also help us to see Western sites in a different light. These different perspectives can relate to the development and function of urban settlements, the organisation and use of urban space, the construction and use of buildings and the lives and experiences of residents. Non-Western perspectives can contribute to an exciting variety of ways of thinking about urbanism and urban spaces. Within archaeology, this decentring of urban studies is even more crucial because of the way in which Western perspectives have conventionally dominated in urban investigations globally, despite there being a huge range of different settlement sites. This is important for thinking about the Roman world, where there were many different types of urban sites across the Empire; they need to be investigated in ways that do not prioritise the Romanocentric perspectives.

Swati Chattopadhyay has argued that the 'West' dominates urban theory and concepts of urbanism are also linked into Western concepts of capitalism and colonialism. ${ }^{4}$ Other types of urbanism are seen as 'beyond the West', but still shaped by comparison with the West. She argues that there is an inability to move beyond the limitations of the Western preoccupation in urban studies and this is especially the case in the study of colonial cities, such as in India. Across the social sciences there has also been recognition of the need to look at the origins of the theoretical discussions and frameworks that have developed within academia in Western contexts. Raewyn Connell, ${ }^{5}$ for example, has argued that we need to involve other cultural traditions from across the world in the development of theory. Western theory has also been critiqued for placing too much emphasis on representing the modern world from economic and rational

3 Edensor - Jayne 2012.

4 Chattopadhyay 2012.

5 Connell 2007. 
perspectives. The philosopher Bruno Latour, ${ }^{6}$ for instance, has emphasised that the concept of 'modern' is problematic, since humans continue to act in many ways that would not be regarded as 'modern'. We can also be more ambitious in the way in which we think about the past, where we also need to be careful in the way in which we project our perceptions of rationality and civilisation onto the past.

One of the key areas that has formed a part of development of post-processual archaeology in Roman studies is that of post-colonialism and the critique of Romanisation. This post-colonial perspective placed an emphasis on critiquing the top-down approach in Roman studies, where the elite Roman perspective had tended to be prioritised. In urban studies, these developments have seen a rise in interest in the relationship between pre-existing peoples and the Roman incomers and the affect this had on urban development. ${ }^{7}$ Important studies, including of individual cities and comparative investigations, have been undertaken across the Empire, looking at the complexity of urban origins and development and emphasising the need to look at local circumstances as well as wider themes. ${ }^{8}$ The urban landscapes and their settings, however, have tended to continue to be treated in fairly conventional ways, including the way in which they have prioritised the Roman perspective in their development.

Across the area of the vast Roman Empire, cities and other settlements existed or developed within different environments and landscapes, and, as such, had different relationships with water. This materiality of urbanism, including water forming part of towns, needs to be understood from the perspective of the people that developed and lived in the settlements and how they experienced them. The theme of urbanism and urban origins in the Roman Empire, especially in the context of provincial expansion, is an area that has tended to be tackled from the perspective of the Roman conquerors and is dominated by the analysis of military activity and the conversion of pre-existing settlements. The relationship between water and urbanism provides an example with which we can develop post-colonial perspectives on urbanism and identity in the Roman period.

Urbanism, urban origins and function, are tackled from the perspective of hierarchies and civilisation as well as the economy, globalisation and networks. We see early on in the development of archaeology an interest in the origins of urbanism and attempts to understand patterns in urban development but the issues are tackled from one perspective. These studies were written within the context of the development of urban studies as a field of interest, all looking with interest to explain and understand urbanism, especially as a result of industrialisation and $20^{\text {th }}$ century economic changes. The archaeologist Vere Gordon Childe devised a model of urban development involving ten categorising points that he regarded as defining urbanism. ${ }^{9}$ These points included such factors as monumental buildings, the production of a surplus and the undertaking of trade activities. These categorisations emphasised the concept of settlement hierarchies where larger cities were regarded as more important than smaller settlements. Karl Wittfogel, in his work 'Oriental Despotism', ${ }^{10}$ argued for the central role of water in the development of early civilisations. He emphasised the concept of the 'hydraulic society' and 'hydraulic despotism' whereby water was used as a form of power. He argued that the control of water supply and irrigation systems led to the creation of a social or governmental structure in these early civilisations, such as in Mesopotamia, India and China.

In the Roman Empire, the differing terrain saw varying levels of accessibility to water across the provinces. This meant that cities could have very different relationships with water. In Britain there is evidence that there could be problems with flooding from rivers and wetlands, and

6 Latour 1993.

7 E. g. Creighton 2006; Revell 2009.

8 E. g. Mladenović 2012; Raja 2012; Haeussler 2013; Reddé - Van Andringa 2015.

9 Childe 1950.

10 Wittfogel 1957. 
we know that this was also the case for Rome itself. Other areas, such as in the Near East and Asia Minor, were much drier and each settlement will have had its own relationship with water and nature. This meant that each town would have had a different experience of water, which will also have included anxieties associated with too much or too little water in their vicinity. With each town, however, we can approach the relationship between the urban fabric and water from similar terms, bringing material and nature together to examine urbanism in a holistic manner.

Studies such as these prioritised a very hierarchical view of urbanism, where cities are regarded as settlements at the top of the hierarchy and are regarded as the most civilised form of settlement. Analyses of these settlements also have a tendency to draw on Western concepts of urbanism, which can create a biased perspective of urbanism and settlement archaeology.

These archaeological studies of urbanism can also be seen as part of a much wider range of urban studies across the disciplines, especially in geography and sociology. The Chicago School of Urban Research, founded in the 1920s, is often seen to have been the most influential in shaping the development of interest in the study of cities and their modern history. One of the early influential publications was Robert Park, Ernest Burgess and Roderick McKenzie's volume 'The City', in 1925, which contained this first chapter by Park, 'The City: Suggestions for the Investigation of Human Behavior in the Urban Environment'. This work represented a style and approach to studying the city that created a homogenous, static and fixed framework for understanding cities. ${ }^{11}$ The early studies originating from the Chicago School often sought to define and characterise the nature of urbanism, but in so doing created a specific view of the city based on the Western perspective and also one that emphasised city hierarchies based on the presence of features regarded as representing urbanism. Park wrote that he saw cities as 'the natural habitat of the civilized man'. ${ }^{12}$ We can see these perspectives in Louis Wirth 1938 and Lewis Mumford's 1961 work. ${ }^{13}$ Mumford saw cities as synonymous with civilisation, and linked with this was also a strong influence from modern concepts of capitalism.

The influences from these traditions, however, also encouraged other perspectives that sought to engage with urbanism, and the experience of urban spaces, differently. French scholars, such as Guy Debord of the situationist movement, developed a perspective of studying urbanism which came to be known as psychogeography. ${ }^{14}$ It sought to avoid Western capitalist perspectives of urbanism and think more about cities as lived spaces. Such approaches have also had some influences on archaeological approaches to place and landscape.

In more recent years, there has been a massive expansion in the range of themes examined in urban studies, especially through the influences of post-modernism and post-colonialism. These influences have seen attempt to move away from the focus on hierarchies and defining characteristics of urbanism, and instead to look at the human experience within settlements and the way in which human activity constituted these settlements. We can see this across disciplines such as geography, sociology and cultural studies with work that examines cultural perceptions of cities, ${ }^{15}$ food and identity, and sensory experiences of cities. ${ }^{16}$

Roman archaeology has never been separate from the influences of developments in other areas of archaeology or influences from other disciplines. We can see this in the way in which themes developed in Roman period urban studies and especially in the study of the processes of conquest and urban development in provincial contexts such as Britain. The majority of accounts relating to urban development in Britain, and other provinces, have tended to be con-

11 Cf. Latham et al. 2009, 2.

12 Park 1952, 14.

13 Wirth 1938; Mumford 1961.

14 Debord 1967.

15 E. g. Highmore 2005.

16 E. g. Edensor 2017. 
cerned with the narrative of conquest and the consolidation of power and control. ${ }^{17}$ Urban development is seen within the context of rational military, economic and geographical concerns with less concern over the people living in the area or the impact of the towns on the landscape. As a consequence, urban development in the Roman period was often divorced from the preexisting uses of the landscape.

More recent developments in archaeological theory have seen more critical perspectives on issues relating to identity, landscape and materiality. In particular, there has been an emphasis on bringing the different perspectives and approaches from processual and post-processual archaeology together into a more symmetrical arrangement so as to create a more balanced approach. ${ }^{18}$ This symmetrical archaeology allows different methodologies and types of material to come together and creates a fuller and more holistic interpretation of the past. This might mean, for example, examining social perspectives of landscape, but also physical, economic, and geographical perspectives and methodologies of landscape. In bringing these different perspectives together, we also need to think about the different ways in which they did interact. In particular, it is important to think about how modern ontologies, the ways of seeing and organising our world, have influenced how we approach the archaeology of the past; ${ }^{19}$ and also whether we can access past ontologies where inhabitants saw and thought about the world differently. Connected with this task is thinking about the relationship between the 'humanmade' and 'non-human' world and how they came together in a way that influences lives and experiences. The study of buildings and settlements is crucial in urban archaeology, for example, but they cannot be separated from the wider landscape in which they were constructed, and so it is necessary to give similar attention to 'natural' or 'non-human' components of these settlements.

This emphasis on the role of the 'natural' or 'non-human' within archaeology has encouraged the advancement of the concept of post-humanism within archaeological studies. ${ }^{20}$ In post-humanism, it is argued that both human and non-human components of the world should be given equal value in studies of the past, such as in landscape and settlement studies, since all of them had an impact on human lives and experiences. ${ }^{21}$ This relationship between human and non-human is also complex because it has been argued that any human involvement or relationship with an unaltered component of the landscape, for example, means that these features cannot be regarded as entirely natural. ${ }^{22}$ The issue of how we understand landscape is also complex, with the term itself reflecting an entirely specific way of viewing and thinking about land, generated in the era of the post-medieval and early modern West. In studying towns, we can think about not only the built structures and people, but also other components, including water. We can think about how the water formed part of these settlements and the impact it had and has on our understanding of the meaning of these sites. This is not only in terms of water supply, such as pipes and aqueducts, but all features of water. Looking at water also helps us address the issue of past ontologies, how water formed part of past experiences.

This recognition of the need to move away from this Western dominance within urban studies is also linked with post-colonial influences and rethinking the role of the subaltern. These developments argue that non-Western forms of urban settlement should not be regarded as inferior to Western forms of urban development. There is also a questioning of the way in which urban settlements are placed in hierarchies of importance with many non-Western or early Western urban sites described as proto-urban rather than urban; Western cities are also seen as

17 E. g. Wacher 1995.

18 Witmore 2007; Webmoor -Witmore 2008; Olsen et al. 2012.

19 DeLanda 2016.

20 E. g. Harris - Cipolla 2017.

21 E. g. Webmoor - Witmore 2008; Olsen et al. 2012.

22 E. g. Bradley 2000. 
superior to non-Western settlements. Tim Edensor and Mark Jayne have argued that we need to decentralise the way in which we approach urban studies. ${ }^{23}$ This means that we need to move urban theory away from a preoccupation with Western urbanism. This is not only about treating non-Western settlements equally, but also thinking about how non-Western sites can be investigated from different, non-Western perspectives, and how these themes can also help us to see Western sites in a different light. These different perspectives can relate to the development and function of urban settlements, the organisation and use of urban space, the construction and use of buildings and the lives and experiences of residents. Non-Western perspectives can contribute to an exciting variety of ways of thinking about urbanism and urban spaces. Within archaeology, this decentring of urban studies is even more crucial because of the way in which Western perspectives have conventionally dominated in urban investigations globally, despite there being a huge range of different settlement sites. This is important for thinking about the Roman world, where there were many different types of urban sites across the Empire; they need to be investigated in ways that do not prioritise the Romanocentric perspectives.

Focusing on Britain, the towns in the Roman period tend to be studied and categorised from the perspective of their legal title and status, which had an impact on the nature of their foundation and development. This categorisation of towns was consolidated by early scholars working on the epigraphic, documentary and archaeological material in order to produce some of the first narratives on urban development in Roman provincial contexts. ${ }^{24}$ This perspective and narrative on urban development has been immensely influential on approaches to provincial archaeology and urbanism, as can be seen in the majority of later publications on Roman Britain. ${ }^{25}$ Martin Millett's 1990 book 'The Romanization of Britain' continued, ${ }^{26}$ but built on, this narrative by emphasising the need to study the pre-Roman context in which each town developed, and the local agency in urban development through interaction with the Roman incomers. This approach has continued to be influential, as can be seen in later publications on urban development. ${ }^{27}$ Later work sought to move away from the Roman-orientated narrative in looking at urban origins by thinking critically about urban biographies and landscapes. ${ }^{28}$ The colonia in Britain were founded from fortresses and they are usually regarded as the most Roman form of cities, followed by the civitas-capitals, which were often located in the context of pre-existing oppida, but could also involve the construction of a fort. The study of towns in Britain has, as a consequence, tended to focus on whether there was a fort associated with the town foundation or not and how these forts influenced the development and nature of the town. This narrative has tended to dominate despite attempts to move towards post-colonial perspectives.

Across the archaeological discipline there is increasing interest in the need to bring social and scientific perspectives of landscape together. In the context of Roman urban studies, however, landscapes have continued to be tackled in fairly conventional ways, which is why there has been increasing dissatisfaction with post-colonialism and critiques of Romanisation, because they continue to prioritise the Roman perspective. Other ways of looking at landscape, however, can help us assess urban development and the materiality of urbanism differently. This is where we can think about not only different perceptions of landscape, but differing ways of reconstructing past landscapes. Post-colonialism helps us to emphasise that we need to look at urban development from a range of perspectives and not simply from that of the top-down analysis. Breaking down dualisms in approaches to archaeological interpretation allows us to bring together different perspectives, including the social and physical implications of water in urban contexts.

23 Edensor - Jayne 2012.

24 E. g. Haverfield 1912.

25 E. g. Frere 1967; Salway 1981; Hurst 1988; Webster 1988.

26 Millett 1990.

27 E. g. Creighton 2006.

28 See Rogers 2016. 


\section{Urban infrastructure and post-humanism: water as part of the urban fabric}

The previous section outlined the way in which studies on urbanism and urban development have tended to be influenced by particular traditions of thinking about urbanism and questions that we ask of the material. Water forms an integral part of urbanism, not just in terms of water supply and drainage, but also the landscape setting and other environmental factors. This section will examine these elements of towns. All watery components will have played a role in influencing urban agency, including how water was encountered, avoided, crossed, obtained and utilised. Where water is not readily available, the demand for water forms a constant impact on human behaviour and action. Water plays a major role in urban lives. Water also forms a non-human presence through human attitudes to, and perceptions of water and beliefs associated with it; water is as much cultural in significance as being of practical necessity. Water formed part of the materiality of towns and how it had an impact on the experience of inhabitants and the development of the settlements. From the perspective of post-humanism, we can treat water as an integral component of towns, just as non-natural components such as buildings. Different ontologies also mean that the meaning of water, and its significance in the landscape, would have been regarded differently than is the case today. This means that we can use the topic of water and urbanism to think about how we can decentre our approach to the study of urbanism and as a consequence also think about issues connected with identity and urbanism.

In studies of Roman period urbanism and water, the theme that has received the most study relates to water supply. This theme includes the study of aqueducts and other sources of supply, such as wells, and also other components of water distribution and drainage, including pipes, lavatories and bathhouses ${ }^{29}$ (Fig. 1). These are all important elements of towns that need to be examined and documented. The difficulty is that these installations and other features tend to be prioritised over wider meaning relating to water and they also tend to be interpreted from the modern perspective of economy, rationality and functionality. The water also formed part of different ontologies and these components of towns may well have been experienced and inter-

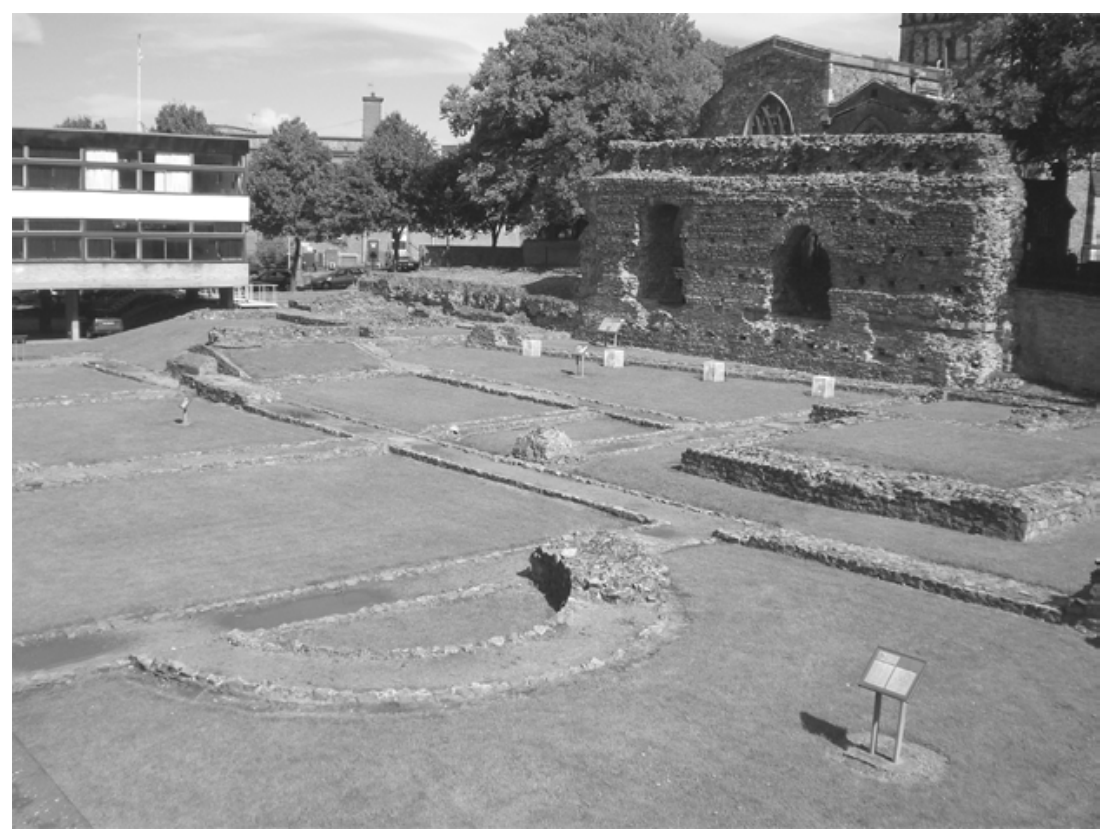

Fig. 1: Leicester (Ratae Corieltavorum), excavated remains of the $2^{\text {nd }}$ century Roman era bathhouse alongside the standing section known as the Jewry Wall. 
preted differently by different groups in the towns. Bathhouses may have been used differently, and not simply in a way that reflects Romanisation, ${ }^{30}$ and aqueducts drew water from meaningful locations. In an interesting paper, Peter Ellis ${ }^{31}$ discussed the potential religious implications on local people in conquered areas of Roman aqueducts drawing water from springs and suggested that they could be a sign of domination. More studies addressing the complexities and meanings in the use of water in the past remain needed. Although aqueducts have received much study in the past, ${ }^{32}$ their religious implications as addressed by Ellis have still only been given minimal attention. The way in which towns in the Roman period interacted with rituallyimbued watery landscapes and local identities is another useful example of the relationship between water and power, which will be explored here through the examination of a few sites.

With post-humanism, we can consider water as an integral component of the landscape, and this landscape also become part of towns as they developed and influenced urban agency. Urban development in Britain in the Roman period tends to be seen within the context of military conquest and the establishment of a network of forts which later became towns. Some towns were also associated with pre-existing oppida which are often treated in the same way as towns. The problem is that these oppida, such as at Colchester (Camulodunum) in Essex, perhaps Camulodunon in the Iron Age, and St Albans (Verulamium) in Hertfordshire, possibly Verlamion in the Iron Age, remain poorly understood and do not easily fall into what might be regarded as the category of an urban settlement. This suggests that we perhaps need to think about these sites in a way that is not preoccupied with Western and modern notions of urbanism. It is also important to consider the fact that the military forts were not founded in deserted landscapes, but were situated in places that already had meaning, history and significance. The water in the landscape formed an important component by which we can examine this.

The relationship between towns and water is not only in the form of rivers and waterfronts, which has key economic significance, but the full relationship between settlement and water can be much more complex. The water can include rivers, streams, lakes, pools, springs, wetlands, islands, puddles, wells, pipes and other forms of supply and water collection and even containers. The distinction between 'natural' and 'artificial' is not straightforward, because the human involvement in all these features breaks down these divisions. The post-human perspective, moreover, ensures that we examine this relationship from not only the human perspective, but also the non-human.

The rationalisation of the landscape led to its secularisation and the neglect of landscape as cosmology and mythical geography, ${ }^{33}$ but by breaking down the dualisms between rational/ scientific and social approaches to landscape, we can develop more holistic perspectives on how landscapes were used, experienced and imagined.

We can document the way in which waterscapes formed part of the urban fabric and how these waterscapes were altered through urban development. Urban development involved interaction with wetlands. At the town of Winchester (Venta Belgarum), for example, there is good archaeological evidence for a large-scale programme of wetland drainage and land reclamation within the floodplain of the Itchen as the town expanded off the island. Excavations in an area of the town known as the Brooks produced evidence of a substantial drainage system with large timber drains to remove the water and make it suitable for building. ${ }^{34}$ There was also evidence of the large-scale dumping of material to build up the land and make it suitable for construction (Fig. 2).

30 Cf. DeLaine 1999; Fagan 1999; Kosso - Scott 2009; Revell 2009.

31 Ellis 1997.

32 E.g. Ashby 1935; Hodge 1991; Hodge 1992; Aicher 1995;.

33 Cf. Darby 1973; Cosgrove 1984; Bender 2001, 3; Johnson 2007.

34 Zant 1993. 


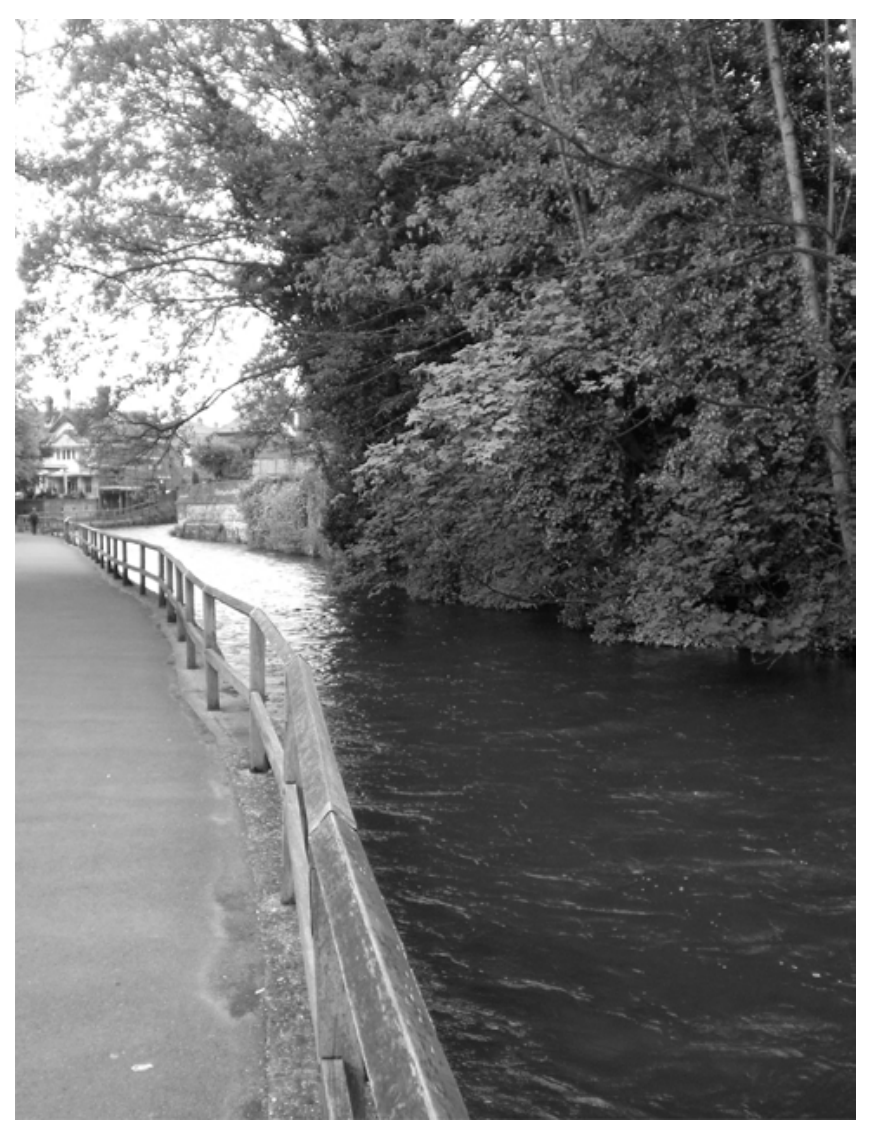

Fig. 2: Winchester (Venta Belgarum), diverted River Itchen, diversion originating in the Roman period.

Rivers and islands also formed part of urban development. The development of London (Londinium) as a town in the Roman period, for example, saw a lot of river canalisation and the construction of revetments, because of the large number of rivers and streams that existed in the area where the town was founded. The main area of the town was constructed on the north side of the Thames where there were a number of smaller rivers and streams flowing into it, including the Walbrook and the Fleet..$^{35}$ Excavations in the Walbrook area have located the course of the Walbrook together with evidence of a series of superimposed revetments, each cutting the silted or backfilled channel of its predecessor. ${ }^{36}$ The first revetment dated to the second half of the $1^{\text {st }}$ century $\mathrm{AD}$ and the preserved remains provided some good evidence of the way in which the revetments were constructed. The evidence consisted of two rows of vertical timbers set in pairs driven into the underlying deposits with horizontal planks set on edge between them and additional planks secured against the outside face. ${ }^{37}$ There was also a large dump of clay behind the revetment, representing consolidation of the ground and the riverbank. The second revetment, probably dating to the $2^{\text {nd }}$ century, consisted of large timbers at least $1.7 \mathrm{~m}$ long and $0.3 \mathrm{~m}$ square, driven their full length into the surface of the bank. Horizontal planks varying from $0.15-0.38 \mathrm{~m}$ wide were fixed to these timbers with nails. A platform connected with this revetment was constructed of heavy wooden planks on a foundation of densely packed vertically driven piles. ${ }^{38}$

On the south side of the Thames at Southwark, settlement developed in a low-lying area where there were a number of islets of raised land with river channels flowing between them.

35 E. g. Maloney - de Moulins 1990; Wilmott 1991.

36 Grimes 1968; Shepherd 1998.

37 Shepherd 1998, 40.

38 Shepherd 1998, 41. 
During the Roman period, this area was gradually transformed and this involved the construction of revetments and the canalisation of river channels. ${ }^{39}$ Excavations of sections of channels have revealed that there were often multiple phases of revetments connected with them. Along the watercourse known as the Southwark Street Channel excavations have produced evidence of two phases of revetment dating to the $1^{\text {st }}$ and $2^{\text {nd }}$ centuries $\mathrm{AD}$, the first of post-and-wattle and the second of post-and-plank construction. The ground level behind them was often raised, and their function was probably to consolidate the channel banks and prevent erosion of the islands..$^{40}$ These actions taken to control and alter waterways will have been significant events, each forming an important element of the river biography and the development of the urban space. Repair work and the building of new installations will have represented continued commitment to the land as well as the attempt to maintain dominance over it.

Another aspect of land use in these urban contexts was the construction of waterfront installations, such as ports and harbours. Port and harbour structures were often created to exploit rivers and seas and to move people and goods more easily. In so doing, they also altered the landscape in major ways and changed the way in which people encountered and interacted with the water. The theme of ports and harbours is a popular area of research across the Roman Empire, but their study conventionally focuses on the themes of trade and transport. ${ }^{41}$ They can, however, also be tied into the way in which waterscapes and the wider landscape were used, exploited and altered. Archaeological evidence at London included remains of sections of timber box quays which were filled in with dumped material, constructed from the AD 60s onwards. ${ }^{42}$ This reshaping of the riverfront into port facilities formed part of the wider landscape transformation as the town developed in London..$^{43}$ The construction of the port, as well as the bridge across the Thames and the treatment of the smaller rivers, were all ways in which water formed part of the materiality of the town. This relationship with water, however, was not as straightforward as simply having purely economic or rational implications, as the next section will examine.

\section{Water and decentring urban agency}

The waterscapes of towns were acted on and utilised by residents, but the water also had other impacts on human action and experience. Breaking down dualisms within archaeological theory allows us to bring perspectives to bear on the meaning and significance of the relationship between towns and water together. That means we can consider the practical implications of water, as part of the urban fabric, on urban agency, but we can also think about the role water had in the meaning of places and the impact water had on human behaviour from social and cultural perspectives. We can approach this impact of water through the way in which water was also associated with religious activity and so already meaningful before the foundation of the towns in the Roman period. It seems likely that the foundation of many of these towns also played a role in the creation or consolidation of group identities, as reflected in the town names, although it is unclear to what extent people felt like they belonged to these groups or whether it was more imposed. Identity, moreover, can also be influenced by places, landscapes and environments, as well as different ontologies and ways of experiencing beyond the brute matter of settlement structures.

\footnotetext{
39 Cowan et al. 2009.

40 Graham 1988; Yule - Hinton 1988, 16.

41 Milne 1985; Jones 2009.

42 Brigham 1998; Milne 1985; Swift 2008.

43 Rogers 2011.
} 
Many of the towns that developed in Britain in the Roman period were associated with landscapes that we can already see were important and meaningful as reflected in evidence relating to water. Evidence for Iron Age settlement associated with water that appears to go beyond what would be considered today practical motives is at the site of the Roman town of Verulamium (near modern St Albans), established at the end of the AD 40s. An Iron Age oppidum and then Roman town was closely integrated with the watery setting here. There were monumental earthworks which appear to have deliberately focused on and incorporated the River Ver and its floodplain. The earthworks date mainly to the $1^{\text {st }}$ century $\mathrm{BC}$ and early $1^{\text {st }}$ century $\mathrm{AD},{ }^{44}$ but there may well have been an earlier focus of activity here, perhaps as a meeting place, before they were constructed. ${ }^{45} \mathrm{~A}$ large enclosure with evidence for coin production may have been a political focus and it was located within the floodplain next to the river. ${ }^{46}$ This location would seem to suggest that the religious meaning attached to the water was an important part of the power of the site and the contribution of facets of identity of those residing there. There was a timber causeway across the river, from which objects appear to have been deposited. ${ }^{47}$ This also led up to an area of probable elite burial at Folly Lane represented by burial mounds, ${ }^{48}$ suggesting that this site was of high status, despite its close association with marshland. The Roman town was placed over the central enclosure within the floodplain, so it continued to incorporate this watery area in a prominent way. Placing the town here may have been a deliberate act relating to the power and control of this meaning-laden place. ${ }^{49}$ Alternatively, the local elite may have contributed towards the development of the town here, because it continued to add meaning to and venerate the site. Tacitus ${ }^{50}$ mentions that the town was a municipium at an early date, and if this was indeed the case, it was clearly of great importance, perhaps reflecting the power and significance attached to the area before the conquest. The construction of the town would have led to the negotiation of new identities and power relations.

Wetlands also saw religious veneration and appear to have played an important part in local identities and power relations. Wetlands, neither water nor land, were the interface between land and water and the world and the underworld. Excavated sites in Britain, such as Flag Fen in Peterborough ${ }^{51}$ and Fiskerton in Lincolnshire, ${ }^{52}$ have demonstrated that wetlands were foci for ritual deposition. One useful example of a large wetland area is the Fenland in East Anglia. Analysis of the quantities of objects ritually deposited in the Fenland of prehistoric and Roman date show that there was a very high concentration here compared with surrounding areas..$^{53}$ Over 200 hoards and single items of Roman date have been documented as having been deposited here. Bronze items included statuettes and other religious regalia, as well as bronze vessel hoards. ${ }^{54}$ There were also hoards of pewter vessels and coins. ${ }^{55}$ The Roman date deposits seem to have been continuing a tradition from prehistory and most of the items were deposited within rivers, streams and marshes. There was also a high concentration of deposited items around the fen-edge, ${ }^{56}$ suggesting that the whole fenland landscape was recognised as special and bounded through religious activity. A number of Roman period shrines were also

44 Thompson 2005, 27-32.

45 Haselgrove 2007, 509.

46 Haselgrove - Millett 1997, 284.

47 Anthony 1970; Niblett 2005, $64 \mathrm{f}$.

48 Niblett 1999.

49 Cf. Millett 1990.

50 Tac. ann. 14, 33 (translation by Jackson 1937).

51 Coombs 1992; Pryor 2001.

52 Field - Parker Pearson 2003.

53 Rogers 2007.

54 E. g. Babington 1883; Taylor 1985, 31.

55 E. g. Liversidge 1959, 7; Poulton - Scott 1993; Denham et al. 1995, 178.

56 Babington 1883, 87; Evans 1984; Gurney 1986, 92; Evans - Hodder 2006. 
Fig. 3: Lincoln (Lindum), Brayford Pool at Lincoln in the low-lying part of the town.

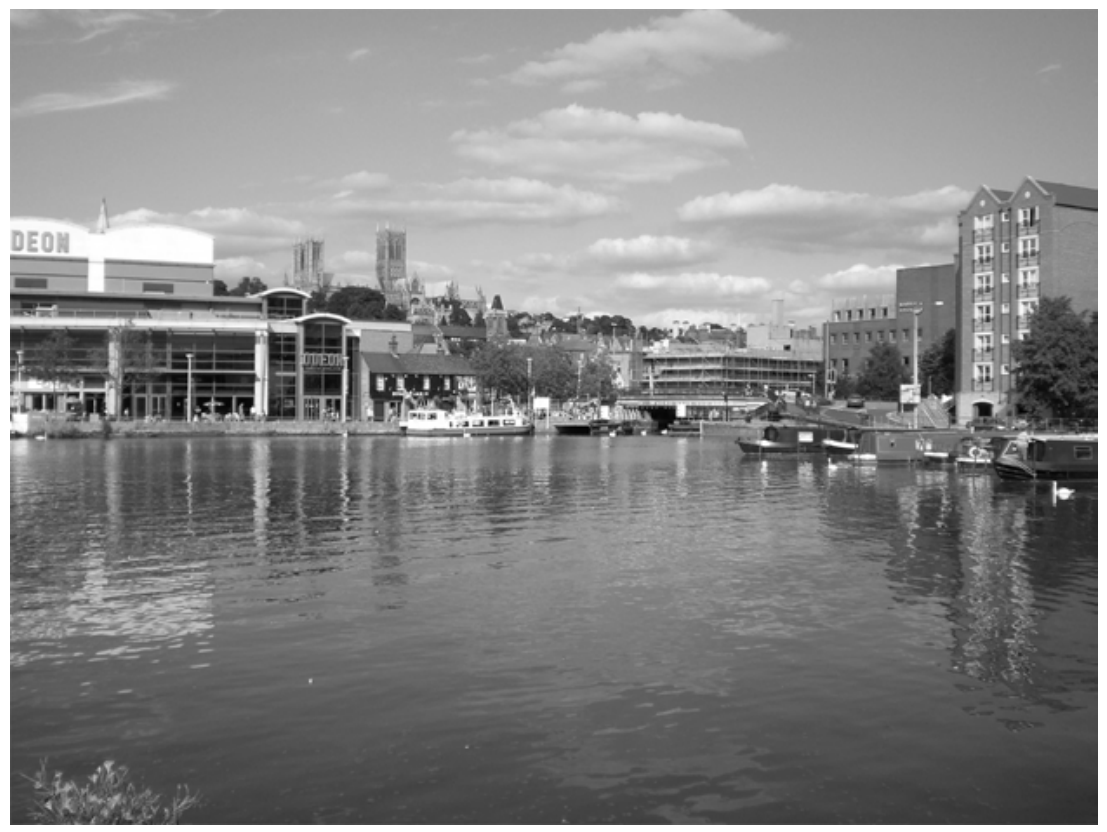

constructed along the fen-edge, a transition zone marking the boundary between the 'treacherous wild Fenland' and rich drier upland ${ }^{57}$ and still greatly susceptible to flooding, ${ }^{58}$ further emphasising the special nature of this area and the influencing aspects of the identity of the local inhabitants. Examples of shrines here include Haddenham on the south-west fen-edge ${ }^{59}$ and Deeping St James on the western fen-edge. ${ }^{60}$ Offerings across the Fenland landscape may suggest the belief of deities within the wetland setting.

North of the Lincolnshire Fens is the city of Lincoln. The Roman era town at Lincoln (Lindum) was preceded by a fortress on the same site, founded at the end of the AD 50s or beginning of the AD 60s. The conversion to a town then took place at the beginning of the AD 70s. The settlements were located on a spot where water formed an important focus in the pre-existing activities and settlement: a marshy location next to the River Witham at the point at which a large natural body of water also formed, known as the Brayford Pool (Fig. 3). There is increasing knowledge of Iron Age activity here, with some timber structures being excavated on what would once have been an island within the Brayford Pool; ${ }^{61}$ the size of the pool is now greatly reduced due to land reclamation (Fig. 4). Very little is known about the nature of the structures on this small island, or the activities associated with them, but the wet conditions here might indicate that a farmstead is unlikely, and instead there may have been some kind of religious and political function here. This watery location certainly appears to have attracted much religious activity, with objects deposited into the Witham and downstream at Fiskerton and then on to the Fenland. A triple-ditched linear earthwork lay to the north of the town site and the Brayford Pool. The definite function and date of this earthwork is still not certain, but a later Iron Age date is perhaps most likely; what excavations there have been along the ditch have found pottery of the $2^{\text {nd }}$ and $1^{\text {st }}$ centuries $\mathrm{BC} .{ }^{62}$ Although it may have functioned as some kind of stock control or barrier, it appears to have been directing attention, perhaps encouraging

\footnotetext{
57 Taylor 1985, 46.

58 Bromwich 1970.

59 Evans - Hodder 2006.

60 Hayes - Lane 1992, 135.

61 Darling - Jones 1988.

62 Jones - Stocker 2003, 30 f.
} 


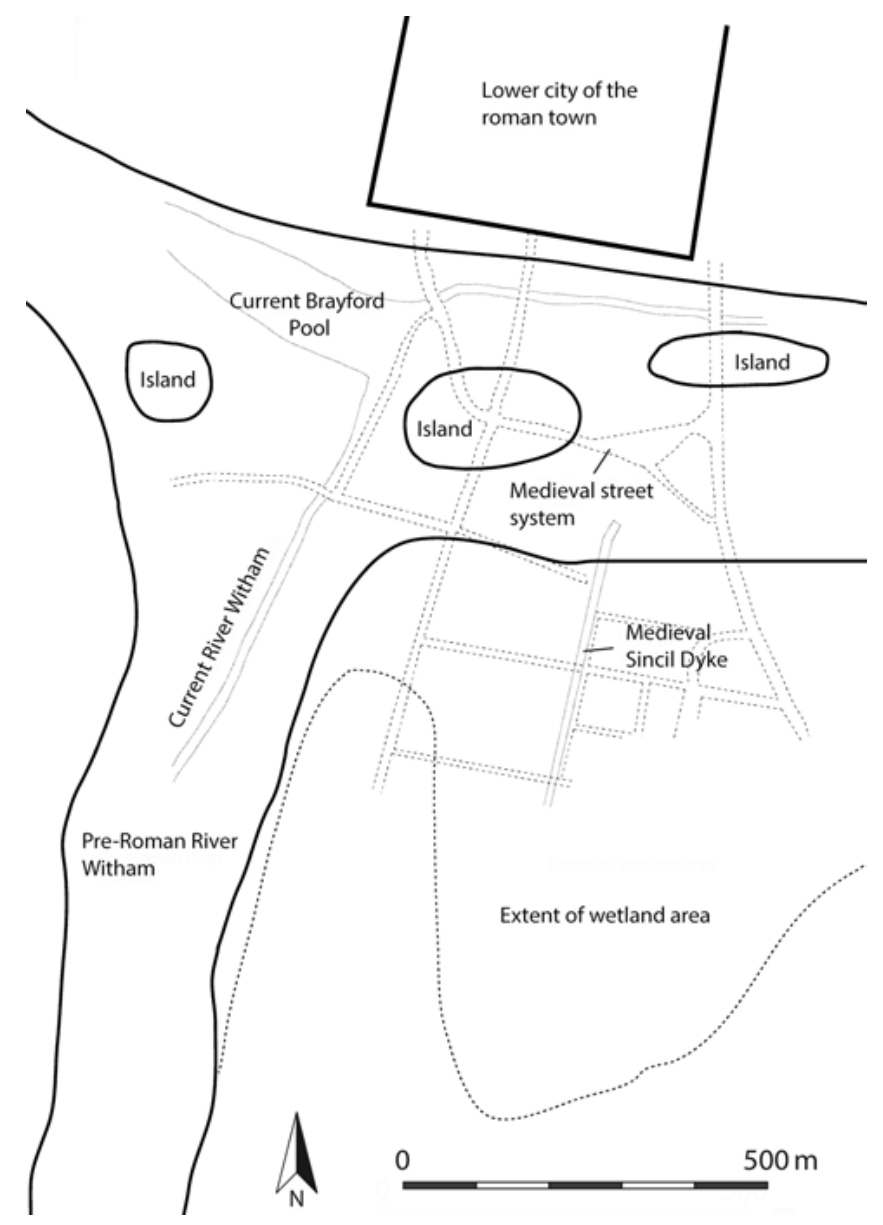

Fig. 4: Lincoln (Lindum), drawing of the Brayford Pool area in the PreRoman and Early Roman periods with a larger River Witham and islands which have now been lost due to reclamation.

movement, towards the watery area, defining religious space and framing the ceremonial. ${ }^{63}$ It may even have controlled access to this site.

There have been suggestions that there was some kind of Iron Age enclosure beneath the Roman fortress. ${ }^{64}$ But apart from a well which may have had pre-Roman origins, and was later incorporated into the site of the forum-basilica, there is still limited evidence for this. Further excavation would be needed beneath the fortress, but chance finds from the wider area do indicate that there was more settlement in the area. Part of the fortress was constructed over the 'Jurassic Way', an ancient route way which follows the line of the Jurassic limestone ridge through Northamptonshire to Lincolnshire, ${ }^{65}$ which might support the idea of a pre-existing site here and the desire to make a physical and symbolic impact in the conquest. Importantly, the city archaeologist for Lincoln has made the observation that the area of the Roman town had many disadvantages from the point of view of establishing settlement, including flooding and difficulties of drainage and supply. ${ }^{66}$ This supports the idea that the fortress, and then town, was placed here for reasons relating more to the domination of pre-existing sites of importance, often with symbolic and religious meanings. It is possible that the Romans recognised the highly charged religious nature of the site and the power attached to it and so placed a fortress here. It may also relate to desires to control the water, as had also occurred in Rome. After foundation,

63 Jones - Stocker 2003, $30 \mathrm{f}$.

64 Gilmour 2007, 231.

65 Gilmour 2007, 231.

66 Jones 2002, 25. 
parts of the wetlands were reclaimed and a section of the river was canalised, ${ }^{67}$ making a large impact on the way in which the area would have been experienced. The local people, especially perhaps the elite, need not necessarily have been against the town if it continued to develop and add to the importance of the site. The watery context remained an important component of the identity of the inhabitants and the experience of the place.

The town at Winchester, established in the late AD 60s or AD 70s, was constructed with its western half overlapping the earthworks of the Iron Age oppidum known as Oram's Arbour alongside the River Itchen, probably dating to the $2^{\text {nd }}$ century $\mathrm{BC}$, but there are also traces of Iron Age activity closer to the river itself. ${ }^{68}$ Neither the Oram's Arbour nor the early Roman town had defences on the eastern side facing the river, suggesting that the floodplain and river were integral parts of the settlement plans and identities of the occupants. The public buildings of the Roman town were constructed on a tufa island within the floodplain of the Itchen, which demanded considerable land reclamation. ${ }^{69}$ The river itself was redirected around the new town, transforming this place through representations of power. There certainly seem to have been more considerations taken regarding the town location here than simply those relating to practicality or economic benefits. The process of town construction would have dramatically altered this area, which it is possible to see as a deliberate act of control and demonstration of power.

Returning to London, we have seen how the landscape was used and altered as the town developed, which will have had an impact on human agency and interaction with the place. Studies of the development of Roman London have always focused on whether there was a military presence in the initial stages of settlement here or whether the town developed firstly as a commercial venture that then later gained prominence and importance. In fact, it seems likely that there was both military and non-military input here during the course of the early stages of development of the town, since even if there was no immediate establishment of a fort or fortress, it does appear that there was a small fort established early in the life of the settlement as identified through excavations at the Plantation Place site. ${ }^{70}$ Despite the uncertainty about the very early stages of settlement at London, it does seem clear that the landscape continued to have an impact on the residents as the town developed and grew. The many rivers and streams that formed part of the waterscape had an impact on human activity and this includes actions associated with religious belief and associated with meanings attached to elements of the waterscape.

The Walbrook stream, which now lies below street level, ran through the town, effectively creating an east and west split. Excavations along the side of where the Walbrook would have flowed in the Roman period have, over the years, identified this zone as quite a focus for religious activity, including a number of temples or shrines, including a mithraeum, and some activities indicated by unusual objects found in the vicinity, including cult pots. ${ }^{71}$ The low-lying and watery nature of the location meant that the mithraeum structure was subject to flooding and there were a number of phases of repair and reconstructing. ${ }^{72}$ This concentration of activity may suggest that this area was religiously important, and this is indicated further by the collection of objects, especially metalwork, uncovered along the river. Much of this material is well preserved because of the wet nature of the deposits. The nature of the deposits suggested that some of it at least was the result of dredging or the movement of material from the river at some point in the past, indicating that the objects may once have been within the river itself. Ralph

67 Jones 2002, 21-24.

68 Qualmann et al. 2004.

69 Zant 1993, 3.

70 Dunwoodie et al. 2015.

71 Bird 1996; Shepherd 1998; Hill - Rowsome 2011; Wardle 2011.

72 Shepherd 1998. 


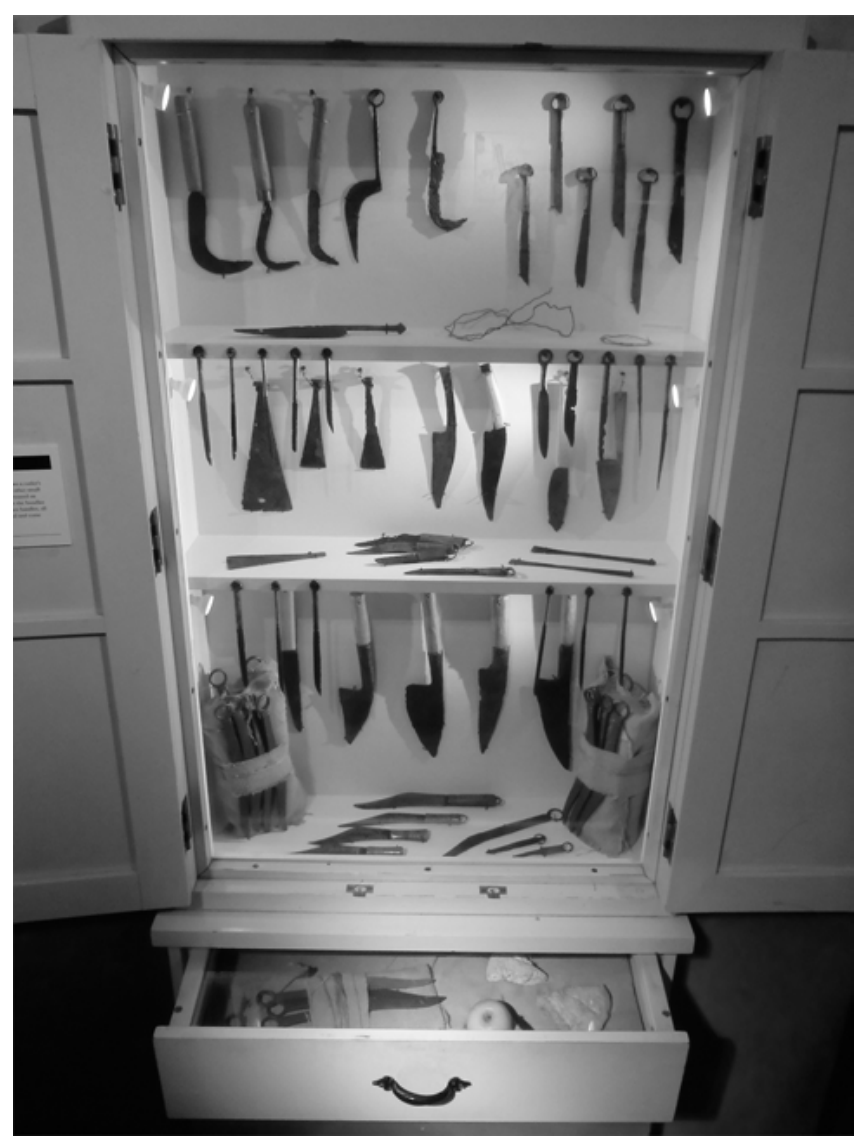

Fig. 5: Museum of London, recreated kitchen of a Roman era house from Londinium containing knives and other metalwork uncovered from the Walbrook stream.

Merrifield ${ }^{73}$ undertook at number of studies of this metalwork, which included a large number of knives and other tools as well as pins and other items. His studies indicated that many of the objects had been deposited in good condition, and some may not even have been used at all, and some appear to have been deliberately bent before deposition. He argued that many of the objects were deposited for reasons relating to ritual or magic, and the location of the stream was an integral component of this activity. Many knives and other metal items are on display in the Museum of London but rarely do the displays acknowledge the complex use lives or multiple meanings of these objects (Fig. 5).

Merrifield's analysis of the objects and their deposition in this watery area of the town shows that the water formed an integral part of the town here and influenced human action and experience of the settlement. The meanings attached to the water formed part of human behaviour, and, as such, the water cannot be separated from other components of the town. The religious or magic activity also tells us about beliefs and also identities within the town. The activity is likely to indicate recognition of the religious importance of the stream and wider location, which continued through the life of the town. The activity is perhaps most likely to have been undertaken by local people that came to live and work in the town, but it may also have been done by incomers from outside Britain that felt the need to recognise the meanings attached to this watery area within the town. 


\section{Conclusions: Water and Roman Era Worlds}

This paper examined water as a component of urban settlement in the Roman period. It explored the way in which water formed part of the materiality of the settlements and the implications and meaning of the water in these contexts. Rather than focusing on the conventional themes of economics, functionality and rationality, the chapter demonstrated that there is more potential in the significance of the water. From a post-humanist perspective, it is possible to treat water as an integral component of the settlements, one which had an impact on human experience, as well as humans acting on the water. The paper examined the way in which water had an impact on the significance and meaning on the sites in which towns developed, how water was used in the towns and how the watery landscapes were developed and transformed as the towns developed. The paper also emphasised this water can be used to develop new perspectives on urbanism and consider the way in which urban development in the Roman period can be approached from a decentred perspective. As such, it emphasised the potential of these settlements to help to access different experiences and identities across the Roman Empire beyond the Roman top-down perspective. The evidence relating to water allows us to decentre our understanding of urbanism and the different experiences people had of water allows us to think in terms of Roman era worlds rather than the Roman world.

\section{Illustration Credits}

Fig. 1: photo by Adam Rogers.

Fig. 2: photo by Adam Rogers.

Fig. 3: photo by Adam Rogers.

Fig. 4: drawing by Adam Rogers, after Steane et al. 2001, fig. 1, 3.

Fig. 5: photo by Adam Rogers.

\section{Bibliography}

\section{Primary sources}

Jackson 1937: J. Jackson, Tacitus. Annales (London 1937).

\section{Secondary literature}

Aicher 1995: P. J. Aicher, Guide to the Aqueducts of Ancient Rome (Wauconda 1995).

Anthony 1970: I. E. Anthony, St Michael's, St Albans, Excavations, 1966, Hertfordshire Archaeology 2, 1970, 51-61.

Ashby 1935: T. Ashby, The Aqueducts of Ancient Rome (Oxford 1935).

Babington 1883: C. C. Babington, Ancient Cambridgeshire (Cambridge 1883).

Bender 2001: B. Bender, Introduction, in: B. Bender - M. Winer (eds.), Contested Landscapes. Movement, Exile and Place (Oxford 2001) 1-18.

Bird 1996: J. Bird, Frogs from the Walbrook: a cult pot and its attribution, in: J. Bird - M. Hassell - H. Sheldon (eds.), Interpreting Roman London. Papers in Memory of Hugh Chapman, Oxbow monograph 58 (Oxford 1996) 119-127.

Bradley 2000: R. Bradley, An Archaeology of Natural Places (London 2000).

Brigham 1998: T. Brigham, The port of Roman London, in: B. Watson (ed.), Roman London. Recent Archaeological Work, JRA. Supplementary series 24, 1998, 23-24.

Bromwich 1970: J. Bromwich, Freshwater Flooding along the Fen Margins south of the Isle of Ely during the Roman Period, in: C. W. Phillips (ed.), The Fenland in Roman Times. Studies of a Major Area of Peasant 
Colonisation with a Gazetteer Covering All Known Sites and Finds, Royal Geographical Society Research Series 5 (London 1970) 114-125.

Chattopadhyay 2012: S. Chattopadhyay, Urbanism, Colonialism and Subalternity, in: T. Edensor - M. Jayne (eds.), Urban Theory Beyond the West. A World of Cities (London 2012) 75-92.

Childe 1950: V. G. Childe, The Urban Revolution, Town Planning Review 21, 1, 1950, 3-17.

Connell 2007: R. Connell, Southern Theory (Cambridge 2007).

Coombs 1992: D. Coombs, Flag Fen Platform and Fengate Power Station Post Alignment - the Metalwork, Antiquity 66, 1992, 504-517.

Cosgrove 1984: D. E. Cosgrove, Social Formation and Symbolic Landscape, Croom Helm historical geography series (London 1984).

Cowan et al. 2009: C. Cowan - F. Seeley - A. Wardle - A. Westman - L. Wheeler, Roman Southwark Settlement and Economy. Excavations in Southwark 1973-91, Museum of London Archaeological Service Monograph 42 (London 2009).

Creighton 2006: J. Creighton, Britannia. The Creation of a Roman Province (London 2006).

Darby 1973: H. C. Darby, The Age of the Improver: 1600-1800, in: H. C. Darby (ed.), A New Historical Geography of England (Cambridge 1973) 302-388.

Darling - Jones 1988: M. J. Darling - M. J. Jones, Early Settlement at Lincoln, Britannia 19, 1988, 1-57.

Debord 1967: G. Debord, La société du spectacle, Collection Folio 2788 (Paris 1967).

DeLaine 1999: J. DeLaine, Introduction: Bathing and Society, in: J. DeLaine - D. B. Johnston (eds.), Roman Baths and Bathing, JRA. Supplementary series 37, 1999, 7-16.

DeLanda 2016: M. DeLanda, Assemblage Theory, Speculative realism (Edinburgh 2016).

Denham et al. 1995: T. Denham - C. Evans - T. Malim - T. Reynolds, Field-Work in Cambridgeshire: September 1994 - May 1996, Proceedings of the Cambridge Antiquarian Society 84, 1995, 167-186.

Dunwoodie et al. 2015: L. Dunwoodie - C. Harward - K. Pitt, An Early Roman Fort and Urban Development on Londinium's Eastern Hill. Excavations at Plantation Place, City of London, 1997-2003, Museum of London Archaeological Service Monograph 65 (London 2015).

Edensor 2017: T. Edensor, From Light to Dark. Daylight, Illumination and Gloom (Minneapolis 2017).

Edensor - Jayne 2012: T. Edensor - M. Jayne, Urban Theory Beyond the West, in: T. Edensor - M. Jayne (eds.), Urban Theory Beyond the West. A World of Cities (London 2012) 1-27.

Ellis 1997: P. Ellis, Pooling Resources - The Use of Water for Social Control in the Roman Empire, in: K. Meadows - C. Lemke - J. Heron (eds.), TRAC 96. Proceedings of the Sixth Annual Theoretical Roman Archaeology Conference, University of Sheffield, March 30th-31st 1996, Theoretical Roman Archaeology Conference 6 (Oxford 1997) 144-150.

Evans 1984: C. Evans, A Shrine Provenance from the Willingham Fen Hoard, Antiquity 58, 1984, 212-214.

Evans - Hodder 2006: C. Evans - I. Hodder, Marshland Communities and Cultural Landscapes, The Haddenham project 2 = McDonald Institute monographs (Cambridge 2006).

Fagan 1999: G. G. Fagan, Bathing in Public in the Roman World (Ann Arbor 1999).

Field - Parker Pearson 2003: N. Field - M. Parker Pearson, Fiskerton. An Iron Age Timber Causeway with Iron Age and Roman Votive Offerings (Oxford 2003).

Frere 1967: S. S. Frere, Britannia (London 1967).

Gilmour 2007: B. Gilmour, Sub-Roman or Saxon, Pagan or Christian: Who Was Buried in the Early Cemetry at St. Paul-in-the-Bail, Lincoln?, in: L. Gilmour (ed.), Pagans and Christians. From Antiquity to the Middle Ages. Papers in Honour of Martin Henig, Presented on the Occasion of his $65^{\text {th }}$ Birthday, BAR. International Series 1610 (Oxford 2007) 229-256.

Graham 1988: A. H. Graham, 64-70 Borough High Street, in: P. Hinton (ed.), Excavations in Southwark 1973-76, Lambeth 1973-79, Joint Publication of the London and Middlesex Archaeological Society and Surrey Archaeological Society 3 (London 1988).

Grimes 1968: W. F. Grimes, The Excavation of Roman and Medieval London (London 1968).

Gurney 1986: D. Gurney, Settlement, Religion and Industry on the Fen-edge. Three Romano-British Sites in Norfolk, East Anglian Archaeology 31 (Norfolk 1986).

Haeussler 2013: R. Haeussler, Becoming Roman? Diverging Identities and Experiences in Ancient Northwest Italy (London 2013).

Harris - Cipolla 2017: O. J. T. Harris - C. N. Cipolla, Archaeological Theory in the New Millennium (London 2017).

Haselgrove 2007: C. Haselgrove, The Age of Enclosure: Later Iron Age Settlement and Society in Northern France, in: C. Haselgrove - T. Moore (eds.), The Later Iron Age in Britain and Beyond (Oxford 2007) 492-522.

Haselgrove - Millett 1997: C. Haselgrove - M. Millett, Verlamion Reconsidered, in: A. Gwilt - C. Haselgrove (eds.), Reconstructing Iron Age Societies. New Approaches to the British Iron Age (Oxford 1997) 282-296.

Haverfield 1912: F. Haverfield, The Romanization of Roman Britain (Oxford 1912).

Hayes - Lane 1992: P. P. Hayes - T. W. Lane, The Fenland Project Number 5. Lincolnshire Survey, the Southwest Fens, East Anglian Archaeology 55 (Sleaford 1992). 
Highmore 2005: C. Highmore, Cityscapes. Cultural Readings in the Material and Symbolic City (Basingstoke 2005).

Hill - Rowsome 2011: J. Hill - P. Rowsome, Roman London and the Walbrook Stream Crossing. Excavations at 1 Poultry and Vicinity, City of London, Museum of London Archaeological Service Monograph 37 (London 2011).

Hodge 1991: A. T. Hodge (ed.), Future Currents in Aqueduct Studies (London 1991).

Hodge 1992: A. T. Hodge, Roman Aqueducts and Water Supply (London 1992).

Hurst 1988: H. Hurst, Gloucester (Glevum), in: G. Webster (ed.), Fortress into City. The Consolidation of Roman Britain in the First Century AD (London 1988) 24-69.

Johnson 2007: M. Johnson, Ideas of Landscape (Oxford 2007).

Jones 2009: J. E. Jones, The Maritime and Riverine Landscape of the West of Roman Britain, BAR. British Series 493 (Oxford 2009).

Jones 2002: M. J. Jones, Roman Lincoln. Conquest, Colonia and Capital (Stroud 2002).

Jones - Stocker 2003: M. J. Jones - D. Stocker, Settlement in the Lincoln Area in the Prehistoric Era: Archaeological Account, in: D. Stocker (ed.), The City by the Pool. Assessing the Archaeology of the City of Lincoln (Oxford 2003) 19-33.

Koloski-Ostrow 2001: A. O. Koloski-Ostrow, Water Use and Hydraulics in the Roman City, Colloquia and conference papers 3 (Dubuque 2001).

Kosso - Scott 2009: C. Kosso - A. Scott, Introduction, in: C. Kosso - A. Scott (eds.), The Nature and Function of Water, Baths, Bathing, and Hygiene from Antiquity through the Renaissance, Technology and change in history 11 (Leiden 2009) 1-18.

Latham et al. 2009: A. Latham - D. McCormack - K. McNamara - D. McNeill, Key Concepts in Urban Geography (London 2009).

Latour 1993: B. Latour, We Have Never Been Modern (Cambridge 1993).

Liversidge 1959: J. Liversidge, A New Hoard of Romano-British Pewter from Icklingham, Proceedings of the Cambridge Antiquarian Society 52, 1959, 6-10.

Maloney - de Moulins 1990: C. Maloney - D. de Moulins, The Archaeology of Roman London I. The Upper Walbrook in the Roman Period, Council of British Archaeology Research Report 69 (London 1990).

Merrifield 1987: R. Merrifield, The Archaeology of Ritual and Magic (London 1987).

Merrifield 1995: R. Merrifield, Roman Metalwork from the Walbrook - Rubbish, Ritual or Redundancy?, TransactLond 46, 1995, 27-44.

Merrifield - Hall 2008: R. Merrifield - J. Hall, In its Depths what Treasures - the Nature of the Walbrook Stream Valley and the Roman Metalwork Found therein, in: J. Clark - J. Cotton - J. Hall - R. Sherris - H. Swain (eds.), Londinium and Beyond. Essays on Roman London and its Hinterland for Harvey Sheldon, Council for British Archaeology Research Report 156 (York 2008) 121-127.

Millett 1990: M. Millett, The Romanization of Britain. An Essay in Archaeological Interpretation (Cambridge 1990). Milne 1985: G. Milne, The Port of Roman London (London 1985).

Mladenović 2012: D. Mladenović, Urbanism and Settlement in the Provinces of Moesia Superior, BAR. International Series 2367 (Oxford 2012).

Mumford 1961: L. Mumford, The City in History. Its Origins, its Transformations, and its Prospects (New York 1961).

Niblett 1999: R. Niblett, The Excavation of a Ceremonial Site at Folly Lane, Verulamium, Britannia Monograph Series 14 (London 1999).

Niblett 2005: R. Niblett, Roman Verulamium, in: R. Niblett - I. Thompson (eds.), Alban's Buried Towns. An Assessment of St Albans' Archaeology up to AD 1600 (Oxford 2005) 41-165.

Olsen et al. 2012: B. Olsen - M. Shanks - T. Webmoor - C. Witmore, Archaeology. The Discipline of Things (Berkeley 2012).

Park 1952: R. E. Park, Human Communities. The City and Human Ecology (New York 1952).

Poulton - Scott 1993: R. Poulton - E. Scott, The Hoarding, Deposition and Use of Pewter in Roman Britain, in: E. Scott (ed.), Theoretical Roman Archaeology. First Conference Proceedings, Worldwide archaeology series 4 (Aldershot 1993) 115-132.

Pryor 2001: F. Pryor, The Flag Fen Basin. Archaeology and Environment of a Fenland Landscape (Swindon 2001). Qualmann et al. 2004: K. E. Qualmann - H. Rees - G. D. Scobie - R. Whinney, Oram's Arbour. The Iron Age Enclosure at Winchester I. Investigations 1950-1999 (Winchester 2004).

Raja 2012: R. Raja, Urban Development and Regional Identity in the Eastern Roman Provinces, 50 BC - AD 250. Aphrodisias, Ephesos, Athens, Gerasa (Copenhagen 2012).

Reddé - Van Andringa 2015: M. Reddé - W. Van Andringa (eds.), La naissance des capitales de cités en Gaule Chevelue, Gallia, Archéologie des Gaules 72, 1 (Paris 2015).

Revell 2009: L. Revell, Roman Imperialism and Local Identities (Cambridge 2009). 
Rogers 2007: A. Rogers, Beyond the Economic in the Roman Fenland: Reconsidering Land, Water, Hoards and Religion, in: A. Fleming - R. Hingley (eds.), The Making of the British Landscape. Fifty Years After Hoskins. Prehistoric and Roman Periods (Macclesfield) 113-130.

Rogers 2011: A. Rogers, Reimagining Roman Ports and Harbours: The Port of Roman London and Waterfront Archaeology, OxfJA 30, 2011, 207-225.

Rogers 2012a: A. Rogers, Water and the Urban Fabric: a Study of Towns and Waterscapes in the Towns of Roman Britain, The International Journal of Nautical Archaeology 41/2, 2012, 327-339.

Rogers 2012b: A. Rogers, Controlling Waterscapes in Urban Contexts in the Roman Period, RBelgPhilHist 90 , 2012, 165-190.

Rogers 2013: A. Rogers, Water and Roman Urbanism. Towns, Waterscapes, Land Transformation and Experience in Roman Britain (Leiden 2013).

Rogers 2016: A. Rogers, The Development of Towns, in: M. Millett - A. Moore - L. Revell (eds.), The Oxford Handbook of Roman Britain (Oxford 2016) 741-766.

Salway 1981: P. Salway, Roman Britain (Oxford 1981).

Shepherd 1998: J. Shepherd, The Temple of Mithras, London. Excavations by W. F. Grimes and A. Williams at the Walbrook (London 1998).

Steane et al. 2001: K. Steane - M. J. Darling - J. Mann - J. Vince - J. Young, The Archaeology of Wigford and the Brayford Pool (Oxford 2001).

Swift 2008: D. Swift, Roman Waterfront Development at 12 Arthur Street, City of London, Museum of London Archaeological Service, Archaeology Studies Series 19 (London 2008).

Taylor 1985: A. Taylor, Prehistoric, Roman, Saxon and Medieval Artefacts from the Southern Fen Edge, Cambridgeshire, Proceedings of the Cambridge Antiquarian Society 74, 1985, 1-52.

Thompson 2005: I. Thompson, Verlamion in the Late Pre-Roman Iron Age, in: R. Niblett - I. Thompson (eds.), Alban's Buried Towns. An Assessment of St Albans' Archaeology up to AD 1600 (Oxford 2005) 23-40.

Wacher 1995: J. Wacher, The Towns of Roman Britain (London 1995).

Wardle 2011: A. Wardle, Finds from the Walbrook deposits, in: J. Hill - P. Rowsome, Roman London and the Walbrook Stream Crossing. Excavations at 1 Poultry and Vicinity, City of London, Museum of London Archaeological Monograph 37 (London 2011).

Webmoor - Witmore 2008: T. Webmoor - C. Witmore, Things Are Us! A Commentary on Human/Things Relations under the Banner of a 'Social' Archaeology, Norwegian Archaeology Review 41, 1, 2008, 53-70.

Webster 1988: G. Webster (ed.), Fortress into City. The Consolidation of Roman Britain, First Century AD (London 1988).

Wilmott 1991: T. Wilmott, Excavations in the Middle Walbrook Valley. City of London, 1927-1960 (London 1991).

Wilson 2000: A. Wilson, Drainage and Sanitation, in Wikander 2000, 151-179.

Wikander 2000: Ö. Wikander (ed.), Handbook of Ancient Water Technology, Technology and change in history 2 (Leiden 2000).

Wirth 1938: L. Wirth, Urbanism as a way of life, American Journal of Sociology 44, 1938, 1-24.

Witmore 2007: C. Witmore, Symmetrical Archaeology: Excerpts from a Manifesto, WorldA 39, 4, 2007, 546-62.

Wittfogel 1957: K. A. Wittfogel, Oriental Despotism. A Comparative Study of Total Power (New Haven 1957).

Yule - Hinton 1988: B. Yule - P. Hinton, 88 Borough High Street, in: P. Hinton (ed.), Excavations in Southwark 1973-76, Lambeth 1973-79, Joint Publication of the London and Middlesex Archaeological Society and Surrey Archaeological Society 3 (London 1988) 71-81.

Zant 1993: J. M. Zant, The Brooks, Winchester, 1987-88. The Roman Structural Remains (Winchester 1993). 
